\title{
ALVAC-CEA (6D)-B7.1 Vaccine
}

National Cancer Institute

\section{Source}

National Cancer Institute. ALVAC-CEA (6D)-B7.1 Vaccine. NCI Thesaurus. Code C29982.

A cancer vaccine consisting of ALVAC, a highly attenuated poxvirus strain derived from the canarypox virus. ALVAC-CEA (6D)-B7.1 vaccine expresses both a highly immunogenic analogue (6D) of the immunodominant epitope of carcinoembryonic antigen (CEA) and B7.1 (also known as CD80), the natural ligand for the T-cell antigen CD28. This agent was designed to stimulate host immune responses against tumor cells that express CEA.

$(\mathrm{NCl04})$ 